\title{
幼少期の心機能を制御する新しい $\mathrm{Ca}^{2+}$ 調節タンパク質の発見とその分子機構
}

\author{
中村(西谷)友重，若林 繁夫 \\ 国立循環器病研究センター研究所・分子生理部
}

\author{
Keywords : \\ $\mathrm{Ca}^{2+}$ sensor, $\mathrm{Ca}^{2+}$ regulation, \\ excitation-contraction coupling. \\ immature heart, cardiac hypertrophy
}

\section{Role of Neuronal Calcium Sensor-1 as a Regulator of Immature Heart Function and Cardiac Hypertrophy}

Tomoe Y. Nakamura-Nishitani, Shigeo Wakabayashi

Department of Molecular Physiology, National Cerebral and Cardiovascular Center, Osaka, Japan

Calcium $\left(\mathrm{Ca}^{2+}\right)$ is an important intracellular messenger that regulates myocyte contraction via excitation-contraction (E-C) coupling and gene transcription underlying cardiac hypertrophy. The mechanisms of E-C coupling in immature hearts are believed to be different from those in adult hearts because of the structural immaturity of the sarcoplasmic reticulum (SR) and T-tubules in an immature heart; however, the details of these mechanisms are not completely understood. Neuronal $\mathrm{Ca}^{2+}$ sensor-1 (NCS-1) is an EF-hand $\mathrm{Ca}^{2+}$-binding protein, which is an important regulator of neuronal functions. Although NCS-1 is expressed in high levels in immature hearts, only little is known about its cardiac functions. In this study, two novel functions of NCS-1 in cardiac tissue was discovered by characterizing the cardiac phenotypes of knockout $\left(\mathrm{NcS}^{-/-}\right)$mice. NCS-1 was found to be a regulator of contraction in immature hearts and that of hypertrophy in adult hearts. NCS-1 promotes Ca ${ }^{2+}$ release from the inositol trisphosphate receptors $\left(\mathrm{IP}_{3} \mathrm{Rs}\right.$ ), followed by $\mathrm{Ca}^{2+} /$ calmodulin-dependent protein kinase II signaling, which results in a large increase in the SR $\mathrm{Ca}^{2+}$ content in an immature heart. In addition, NCS-1 expression increased during the early stages of hypertrophy in the adult heart; and phenylephrine-induced cardiac hypertrophy was largely attenuated in $N c s 1{ }^{-/-}$ hearts. Our results revealed a novel mechanism of E-C coupling in immature hearts and another regulatory mechanism involved in the progression of receptor stimulation-elicited cardiac hypertrophy.

\section{要旨}

心臓の収縮や心肥大 · 心不全の発症を調節するものとして, 細胞内カルシウム $\left(\mathrm{Ca}^{2+}\right)$ の増減が重要なカギとなっ ている。しかし, 胎児期や幼少期などの未成熟期の心臓では, 細胞内 $\mathrm{Ca}^{2+}$ 貯蔵装置である筋小胞体 (SR)の構造が成

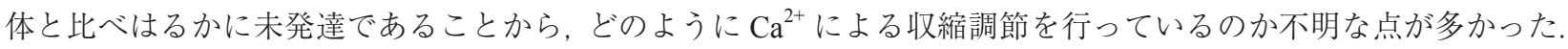
今回, 特に未成熟期の心臓に高発現する $\mathrm{Ca}^{2+}$ 結合タンパク質 (Neuronal $\mathrm{Ca}^{2+}$ Sensor-1: NCS-1)に注目し, 遺伝子欠損 (KO) マウスを解析した結果, NCS-1 が幼少期の構造的な未熟さを補う新しい心筋収縮調節夕ンパク質であることを 見出した. 詳しい解析から, NCS-1 は細胞内に $\mathrm{Ca}^{2+}$ を放出するイノシトール三リン酸 $\left(\mathrm{IP}_{3}\right)$ 受容体と協同して $\mathrm{Ca}^{2+}$ シ グナルを増強させることにより，幼少期の心筋収縮に寄与することを明らかにした ならず心肥大の際にも発現量が上昇し, 心肥大を調節することがわかった. 本稿では, 心蔵における NCS-1を介し た細胞内シグナルとその役割について，最近の知見をもとに概説する.

特別寄稿：第 16 回日本小児心血管分子医学研究会特別講演より

2013 年 12 月 16 日受付

2014 年 2 月 14 日受理
別刷請求先：干 565-8565 大阪府吹田市藤白台 5-7-1

国立循環器病研究センター研究所・分子生理部 中村(西谷)友重 


\section{成体心筋における興奮収縮連関}

(E-C カップリング)

心臓は, 主に心筋細胞とそれ以外の線維芽細胞など から構成されているが, 成体の心筋細胞は, 核, ミトコ ンドリア以外に筋原線維と呼ばれる収縮性の細胞内小 器官, 網目状の発達した筋小胞体 $(\mathrm{SR})$, そして $\mathrm{T}$ 管と 呼ばれる細胞膜が陥入してできた管状の膜構造から成 り立っている(Fig. 1A)，T管はSR と各所で接触してい るため, 細胞膜の活動電位を速やかに SR に伝達し, 筋 原線維が一斉に収縮を引き起こすのに効率のよい構造 をとっている，成体心筋における E-C カップリングの 機構をまとめると, まず心筋細胞に活動電位が発生す ると, $\mathrm{T}$ 管に局在する電位依存性 L-タイプカルシウム $\left(\mathrm{Ca}^{2+}\right)$ チャネルが開口し $\mathrm{Ca}^{2+}$ が流入する。これが引き 金となって $\mathrm{SR}$ から $\mathrm{Ca}^{2+}$ 遊離チャネルであるリアノジ ン受容体 $(\mathrm{RyR})$ を通って大量の $\mathrm{Ca}^{2+}$ が放出され $\left(\mathrm{Ca}^{2+}\right.$ induced $\mathrm{Ca}^{2+}$ release) , 大きな細胞内 $\mathrm{Ca}^{2+}$ の増加が認め
られる。この $\mathrm{Ca}^{2+}$ が筋原線維の中のトロポニン $\mathrm{C}$ と結 合し, 筋収縮が起こる, その後, $\mathrm{Ca}^{2+}$ は再び $\mathrm{SR}$ に取り 込まれるか, $\mathrm{Na}^{+} / \mathrm{Ca}^{2+}$ 交換輸送体 (NCX)により細胞外 へとくみ出され，筋弛緩が生じる。このように，成体で は SR が収縮のための主な $\mathrm{Ca}^{2+}$ 供給源であり, SR 依存 的な E-C カップリングの機構が存在する (Fig. 1B).

\section{幼少期と成体の心臓の違い}

一方, 胎児期や幼少期などの未成熟期では, 心筋細 胞の微細構造, ならびに細胞内 $\mathrm{Ca}^{2+}$ 濃度調節を行う夕 ンパク質の発現様式が成体とは異なることが報告され ている。このことから成体とは異なる E-Cカップリン グの機構が存在するのではないかと考えられている が，詳細は不明である

たとえば Fig. $2 \mathrm{~A}$ は, 成体拧よび生後 1 週齢の幼少期 マウスの心筋細胞の T 管を染色したものである(ここ では，マウスを用いた実験系において，生後1日目か
A

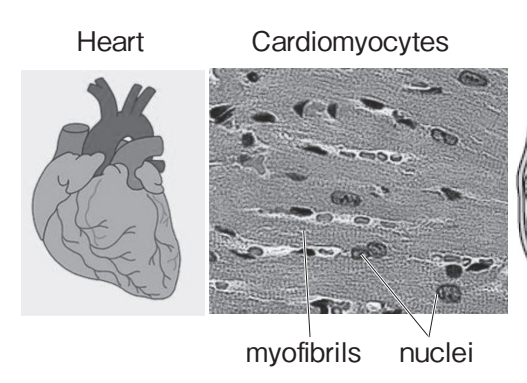

B
Ultrastructure of cardiomyocytes

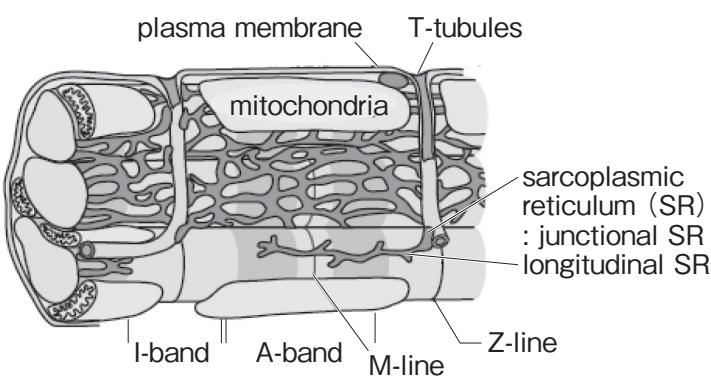

M-line

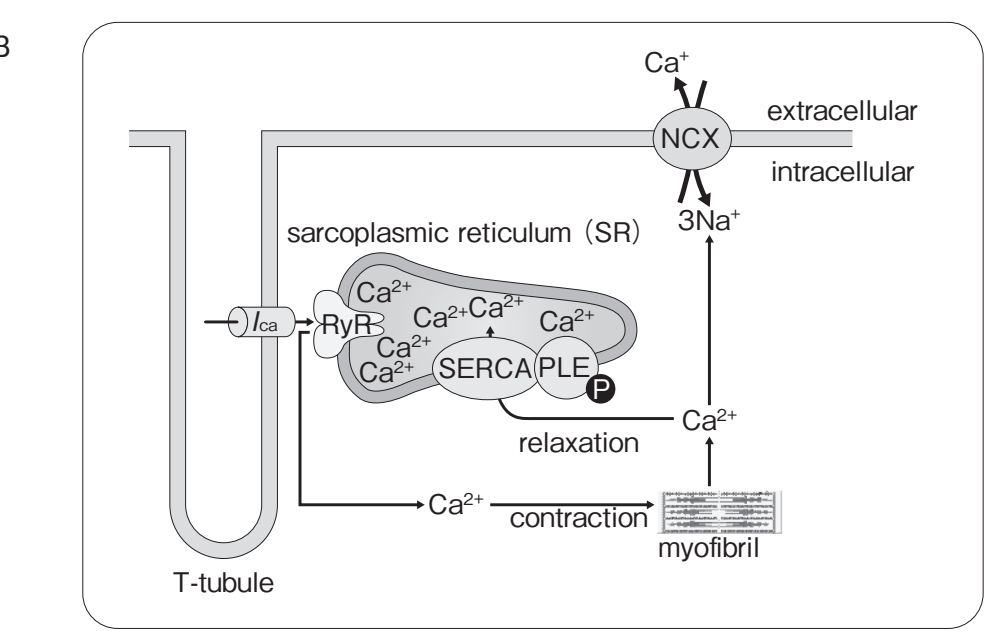

Fig. 1 The structure and the proposed mechanism of excitation-contraction (E-C) coupling in adult cardiomyocytes. A: Heart and cardiomyocytes: structure.

B: E-C coupling mechanism of mature cardiomyocytes.

Ica: L-type $\mathrm{Ca}^{2+}$ channels, RyR: Ryanodine receptor, SERCA: sarcoplasmic reticulum $\mathrm{Ca}^{2+}$-ATPase, PLB: phospholamban, $\mathrm{NCX}: \mathrm{Na}^{+} / \mathrm{Ca}^{2+}$ exchanger 
A

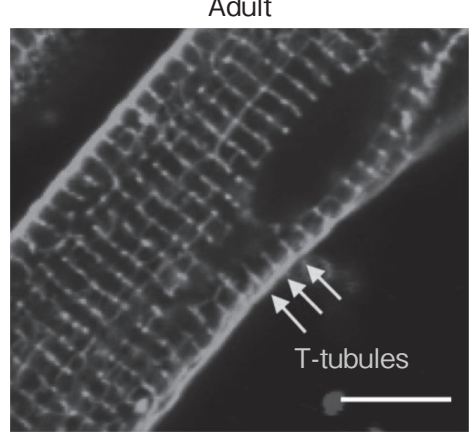

B

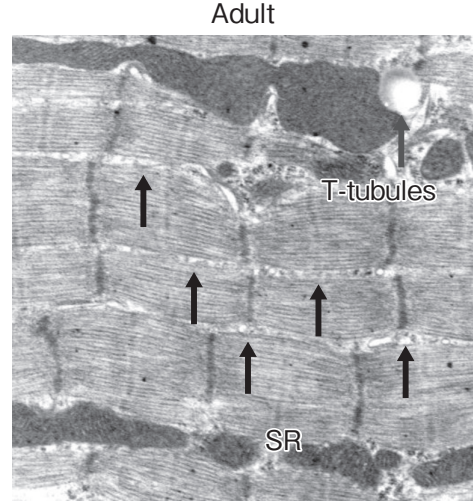

1-week-old

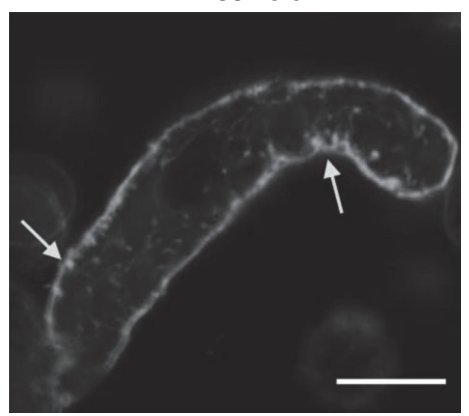

1-day-old

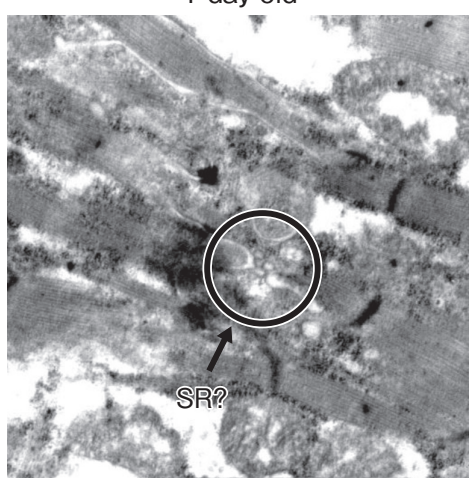

Fig. 2 Structural differences observed between adult and neonatal mouse cardiomyocytes. A: T-tubule staining with di-8-ANEPPS of ventricular myocytes from adult and 1-week-old mice B: Ultrastructure of cardiomyocytes from adult and 1-day-old mice.

Note that immature cardiomyocytes have less T-tubules and SR.

ら 2 週齢までを“幼少期”, また生後 6 週齢以降を“成 体”と呼ぶこととする)。成体でははっきりとした $2 \mu \mathrm{m}$ 毎の繰り返し構造が認められるのに対し, 幼少期では ほとんど T管が認められない.またさらに詳細な電顕 像で, 成体では数多く認められた SR が, 生後 1 日目の マウスでは非常にまばらであり，また筋原線維の配列 も不整であることがわかった(Fig. 2B)。これらの微細 構造の違いから, 幼少期マウスの心筋細胞ではSRに 依存したE-Cカップリングは起こりにくいのではない かと予測される，さらに，胎児期，幼少期などの未成熟 期では, 種々の $\mathrm{Ca}^{2+}$ 濃度調節タンパク質の発現パター ンが異なることが知られている4 いて E-C カップリングの主要な役割を担う L-タイプ $\mathrm{Ca}^{2+}$ チャネルや $\mathrm{RyR}$ の発現は胎児期や出生直後では低 く, 逆に T-タイプ $\mathrm{Ca}^{2+}$ チャネルや NCX の発現量は高 い. 実際, $\mathrm{NCX} の \mathrm{Ca}^{2+}$ 流入モードの活性化により出生 直後の心筋が収縮したことから5 ${ }^{5)}$, 胎览期や出生直後で は, SR からの $\mathrm{Ca}^{2+}$ 放出よりも NCX な゙を介した形質 膜からの $\mathrm{Ca}^{2+}$ 流入が心筋収縮により大きな寄与をする のではないかと考えられてきた. しかし，それ以降の 幼少期では，T管や SR の構造が未発達であるにもかか
わらず， $\mathrm{SR}$ からの $\mathrm{Ca}^{2+}$ 遊離を阻害すると収縮が障害 されることから, SR がやはり収縮のための大きな $\mathrm{Ca}^{2+}$ 供給源であることは疑いない。このことは, 幼少期に は構造的な未熟さを補う未知なる調節因子が存在する ことを示唆している. 本研究により, 幼少期に高発現 する $\mathrm{Ca}^{2+}$ 結合夕ンパク質(Neuronal $\mathrm{Ca}^{2+}$ Sensor-1: NCS-1) が，その調節因子の一つであることが明らかとなっ $た^{1,2)}$.

\section{NCS-1 とは}

心臟において, 細胞内 $\mathrm{Ca}^{2+}$ はさまざまな生体応答の キー因子である。しかし, 多くの夕ンパク質は単独で は $\mathrm{Ca}^{2+}$ に結合することはできないため, カルモジュリ ンなどの $\mathrm{Ca}^{2+}$ 結合タンパク質との結合を介して, 細胞 内 $\mathrm{Ca}^{2+}$ 濃度変化を感知し, 収縮や遺伝子発現などを調 節している。

NCS-1 は, このような $\mathrm{Ca}^{2+}$ 結合タンパク質の一つで あるが, すべての組織に普遍的に存在するカルモジュ リンとは異なり, 神経をはじめとする興奮性組織に特 に高発現している，そのため，その役割も興奮性細胞 
特異的な機能の調節に関わっていると考えられる. 分 子量 $22 \mathrm{kDa}$ の小さなタンパク質で, 分子内に 4 つの $\mathrm{EF}$ ハンド $\left(\mathrm{Ca}^{2+}\right.$ 結合 $)$ モチーフを持つ.アミノ末端は脂質 修飾(ミリストイル化)されており, 膜への結合に必須 とされている (Fig. 3A).

もともと NCS-1 を高発現するショウジョウバエが過 剰な興奮性作用を示すことから，神経のシナプス伝達 に関わる因子として知られていた。また, NCS-1 はシ グナル伝達で重要な役割を担うイノシトールリン酸化 酵素 PI4K の活性化や，さまざまなイオンチャネルの活 性制御6)を介して神経の興奮性を調節し, シナプスの可 塑性や記憶などにも関与していることが報告されてい る3)、私たちは，障害を受けた神経の生存率を上げる働 きがあることを報告している7)。さらに, NCS-1 は神経 のみならず, 未成熟期の心筋においても高発現するこ とを見出していたが8)，心臟におけるNCS-1の役割に ついては全く不明であった。

\section{幼少期の心筋における NCS-1 の役割}

NCS-1 の心臓における役割, 特に幼少期における役 割を明らかにするため, 各発達段階における発現量を 比較したところ, NCS-1 は胎児期や幼少期などの未成 熟期に発現量が高く, 次第に減少していくことがわ かった(Fig. 3B)。またNCS-1 は, 生後マウスの心筋細 胞内で形質膜および核膜周辺のほか, $\mathrm{SR}$ などの $\mathrm{Ca}^{2+}$ シグナル関連部位に集積していたことから, NCS-1 が 幼少期の心筋細胞の $\mathrm{Ca}^{2+}$ シグナル調節に関与している ことが示唆された。

NCS-1 の心臓における役割を明らかにするため, 全 身遺伝子久損 $(\mathrm{KO})$ マウス (Fig. $3 \mathrm{C}$ inset) を用い種々の 解析を行った，興味深いことに，KO 群では出生したマ ウスの $30 \%$ が生後 4 日目までに死亡した(Fig. 3C)。ま た心エコーにより心機能を解析した結果, 生後 2 週齢 の幼少期のマウスでは, 左室の収縮率が顕著に低下し ていた(Fig. 3D)。一方, 6 週齢の成体マウスでは, WT と KO で収縮率に違いは認められなかった. 次に, 幼 少期マウスの心機能低下の原因として, 細胞内 $\mathrm{Ca}^{2+}$ 卜 ランジェントに違いがあるか WT と KO で比較したと ころ, $\mathrm{KO}$ 心筋では収縮期における $\mathrm{Ca}^{2+}$ レベルが顕著 に低下していた(Fig. 3E)。また, SRの $\mathrm{Ca}^{2+}$ 貯留量も WT と比べかなり低くなっていた (Fig. 3E).すなわち $\mathrm{KO}$ 心筋は, $\mathrm{SR} の \mathrm{Ca}^{2+}$ 貯留量が低下することにより, 細胞内 $\mathrm{Ca}^{2+}$ トランジェントおよび筋収縮力が低下して いると考えられたので, 次にどのような機序で SRの $\mathrm{Ca}^{2+}$ 貯留量が低下しているのかを解析した。
$\mathrm{SR}$ の $\mathrm{Ca}^{2+}$ 貯留量は, $\mathrm{SR}$ から $\mathrm{Ca}^{2+}$ を放出する $\mathrm{RyR}$ および $\mathrm{SR} へ \mathrm{Ca}^{2+}$ を取り达む $\mathrm{Ca}^{2+}$ ポンプの活性によっ て決まる。また $\mathrm{SR} \mathrm{Ca}^{2+}$ ポンプの活性は, その調節タン パク質であるフォスフォランバン (PLB)のリン酸化の 程度によって決まるが, そのリン酸化を起こす酵素は $\mathrm{Ca}^{2+} /$ カルモジュリン依存性キナーゼ II (CaMKII) ある いはPKAである.PLBがこれらリン酸化酵素によりリ ン酸化されれば $\mathrm{SR} \mathrm{Ca}^{2+}$ ポンプの活性が高くなり, そ の結果 $\mathrm{SR}$ の $\mathrm{Ca}^{2+}$ 貯留量が高くなる. 詳しい解析から, KO 心筋では, PLBの CaMKII によるリン酸化量が顕著 に低下しており, また実際, CaMKII のリン酸化そのも のも, さらに $\mathrm{SR} \mathrm{Ca}^{2+}$ ポンプ活性も低下していること がわかった，一方，心筋内のほかの多くの $\mathrm{Ca}^{2+}$ 関連夕 ンパク質, たとえば電位依存性 L-タイプ $\mathrm{Ca}^{2+}$ チャネル, $\mathrm{T}$-タイプ $\mathrm{Ca}^{2+}$ チャネル, NCX, カルセクエストリンな どの量は WT と KO 間で差は認められなかった1). 以上 の結果から, NCS-1 は心筋に扔いて CaMKII を活性化 し, CaMKIIによるPLBのリン酸化を介して SR Ca ポ ンプ活性を上昇させ, $\mathrm{SR} \mathrm{Ca}{ }^{2+}$ 貯留量を上昇させること により，構造的に未熟な SRでありながらも細胞内 $\mathrm{Ca}^{2+}$ レベルおよび心筋収縮力を上昇させているのでは ないかと考えられた(Fig. 4A).

次に, NCS-1 がどのようにして CaMKII を活性化す るのかについて, NCS-1 の標的タンパク質を探索した. 細胞内 $\mathrm{Ca}^{2+}$ レベルを上昇させ, しかも NCS-1 と結合す るタンパク質として,イノシトール三リン酸 $\left(\mathrm{IP}_{3}\right)$ 受容 体が有力な候補として浮上した，IP3 受容体は, RyR と 同じく $\mathrm{SR}$ 上の $\mathrm{Ca}^{2+}$ 遊離チャネルであるが，心筋にお いてはRyR と比べ発現量が顕著に低いため, その役割 が長らく不明であった。しかし近年, IP3 受容体は未成 熟心筋の発生や, 心肥大・心不全に関連することが報 告されている ${ }^{9 \sim 11}$. IP 3 受容体は 1 ～ 3 の 3 つアイソ フォームが存在するが, タイプ 1 がほとんどすべての 細胞に存在するのに対し, タイプ 2 が心筋の主要なア イソフォームである。最近, NCS-1 が神経において IP3 受容体タイプ 1 と結合することが報告されていること から，心筋でも同様な NCS-1 との相互作用が起こるか 検討した. その結果, NCS-1 と IP3 受容体(タイプ 1 と2) は $\mathrm{Ca}^{2+}$ 依存的に免疫沈降した。また, 脂質二重膜を用 いた IP3 受容体タンパク質の再構築系において, 精製 NCS-1 タンパク質の添加は, IP3 受容体チャネルの開口 確率を増加させることが報告されているが12,13), 実際, $\mathrm{KO}$ 心筋を用いた系で, $\mathrm{IP}_{3}$ 受容体刺激による $\mathrm{Ca}^{2+}$ 上昇 が軽減された ${ }^{1)}$ 。さらに, NCS-1, IP 3 受容体, CaMKII を高発現させた細胞系に抒いて, IP 3 受容体アゴニスト によってリン酸化 CaMKII の量が顕著に上昇し，それ 


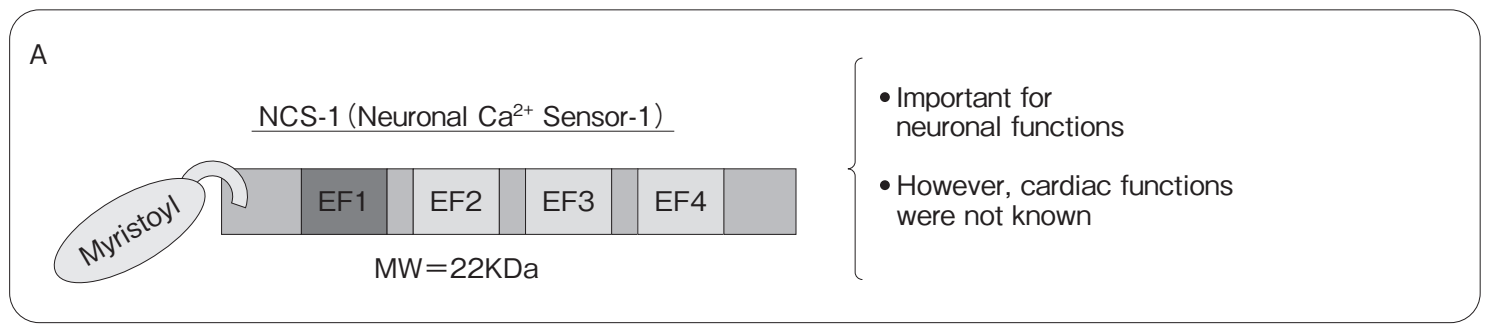

B
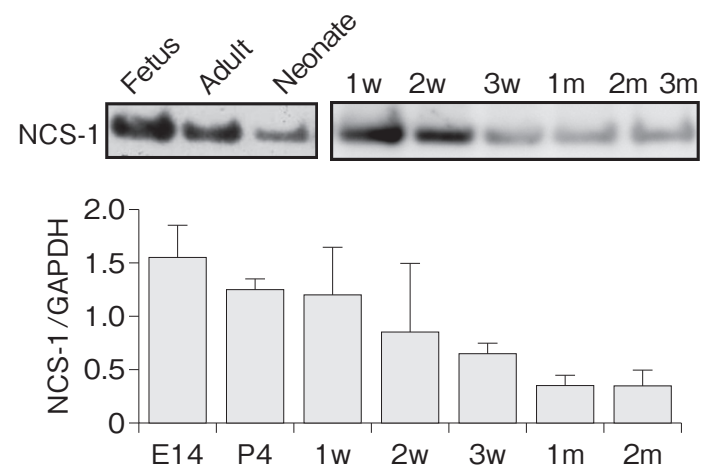

C

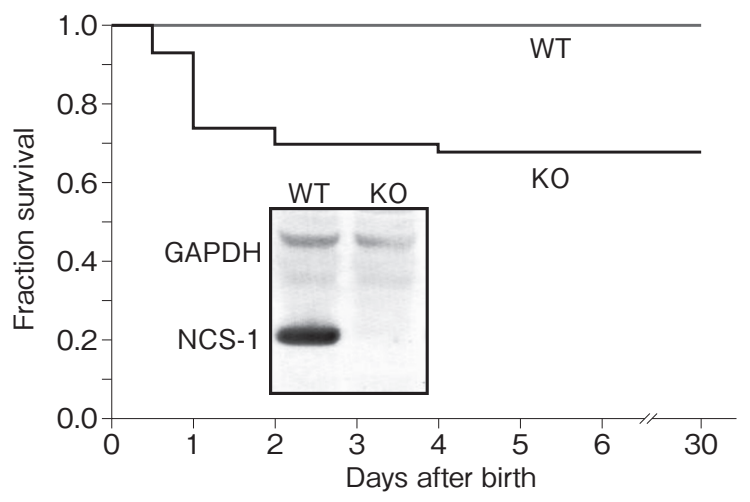

D WT 2 week-old KO
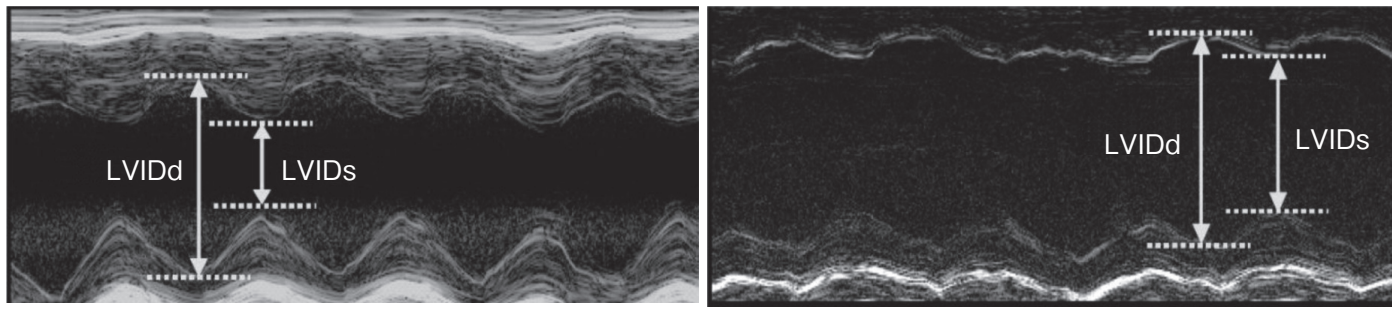

$\mathrm{E}$
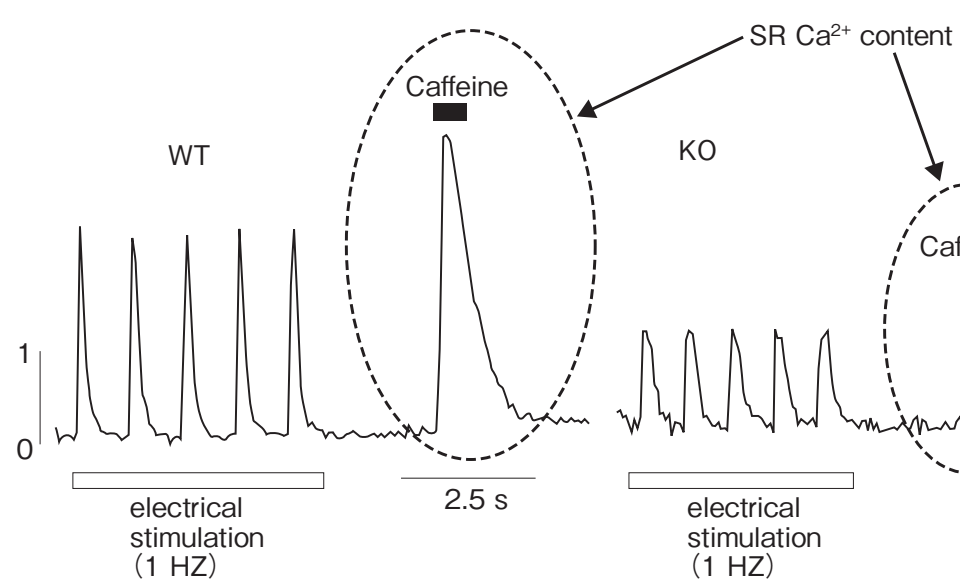

$0.1 \mathrm{sec}$

Fig. 3 Characterization of NCS-1 deficient mice.

A: The schematic structure of NCS-1.

B: The expression levels of NCS-1 during the development of the mouse heart. E14, 14-day-old embryos; P4, 4-day-old neonates; 1 to $3 \mathrm{w}, 1$ to 3 week-old juveniles; and 1 to $2 \mathrm{~m}, 1$ - to 2 -month-old adults.

C: Survival curve of $\mathrm{KO}$ mice indicating reduced survival rate.

D: M-mode echocardiographic images from 2-week-old mice. LVIDd and LVIDs indicate left ventricular diastolic and systolic internal dimension, respectively.

E: Electrical stimulation-elicited $\mathrm{Ca}^{2+}$ transients measured with Fluo-4 AM. Caffeine-induced $\mathrm{Ca}^{2+}$ transients (shown inside the dotted circles) were also measured to estimate the SR $\mathrm{Ca}^{2+}$-content. Pannels B-E are reprinted from the Circ Res 2011; 109: pp512-523. 


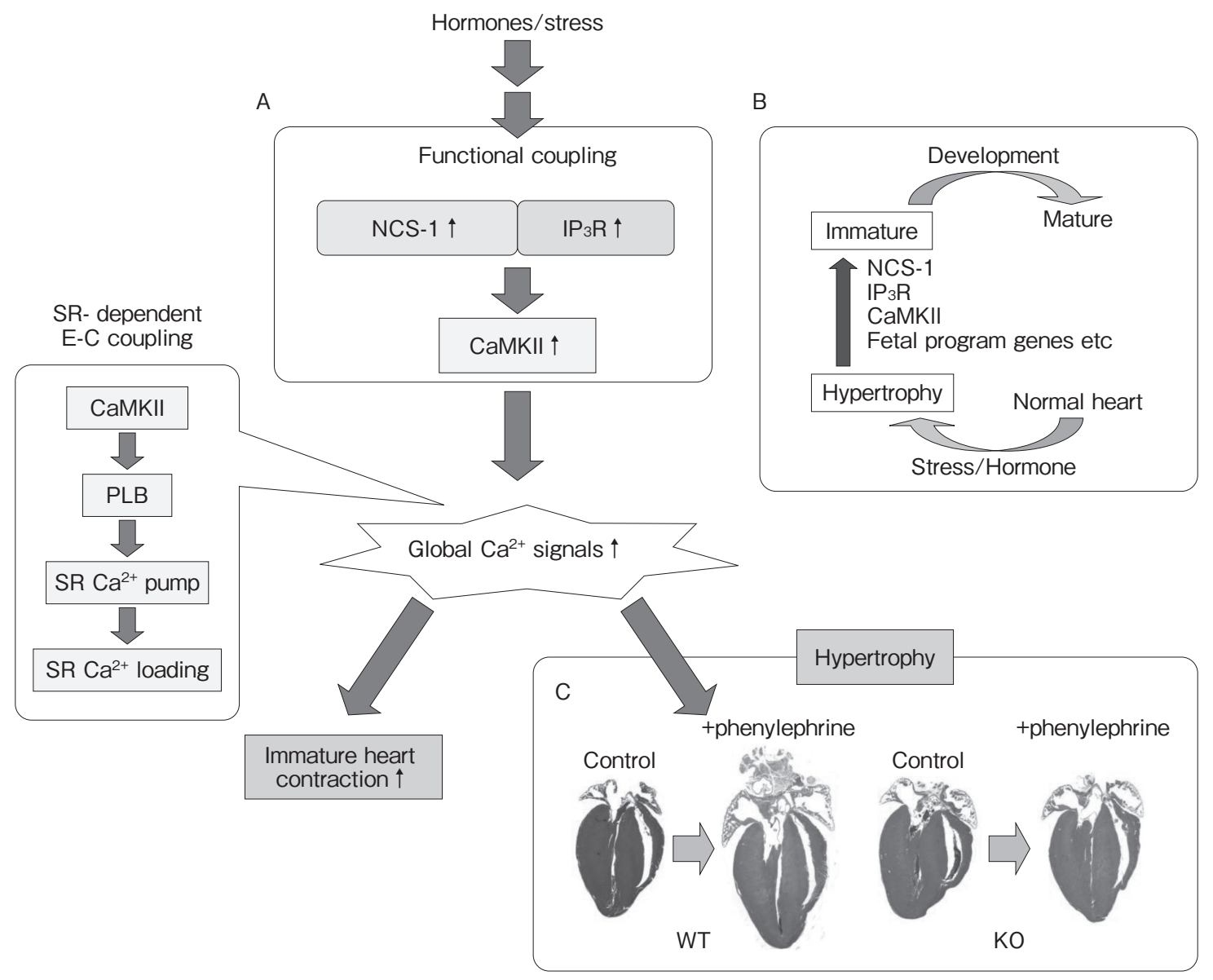

Fig. 4 Role of NCS-1 in the heart.

A: NCS-1 acts as a positive regulator of contraction in an immature heart

B: The expression level of various genes (NCS-1, IP3Rs, CaMKII, etc.) upregulated during the development increases at cardiac hypertrophy.

C: Phenylephrine-induced cardiac hypertrophy was largely attenuated in the KO mice. Reprinted from the Circ Res 2011; 109: $\mathrm{pp} 512-523$.

がIP3 受容体阻害剂で抑制された1)。以上の結果より， NCS-1 が心筋において IP3 受容体のチャネル活性を克 進させ，引き続きCaMKII を活性化させていることが 明らかとなった(Fig. 4A)。このような, 幼少期マウス における NCS-1, IP3 受容体, CaMKII の機能連関によ る心筋収縮力の増大は, これらすべてのタンパク質が 幼少期にそろって高発現していること1)からも理解で きる.また, 培養マウス心筋細胞では自動拍動の際の 細胞内 $\mathrm{Ca}^{2+}$ トランジェントは KO に比べて WT のほう が大きいが, CaMKII の阻害剤添加により KO なみに減 少した ${ }^{1)}$. すなわち WT と KO の細胞内 $\mathrm{Ca}^{2+}$ トランジェ ントの差は, CaMKII 活性に依存していることからも, NCS-1, IP3 受容体, CaMKII の機能連関の存在が示唆さ れる。一方, 成体心筋では SR や T 管が発達し, これら タンパク質に依存しなくても効率のよい E-C カップリ ングを行えるため, WT と KO マウスで心筋収縮力に
あまり差が認められなかったのではないかと推測で きる。

\section{NCS-1 と心肥大との関連}

未成熟期に高発現するタンパク質は，その多くが心 肥大の際にも誘導され心肥大形成を調節することが知 られている ${ }^{14)}$ (Fig. 4B). NCS-1 が肥大心筋において発 現量が充進し, さらに IP3 受容体も心肥大に寄与する ことから ${ }^{9)}$, 次に NCS-1 と心肥大との関連について検 討した。

その結果, (1) NCS-1 は, 心肥大誘発因子であるフェ ニレフリンやエンドセリン 1 により, 発現量が上昇 し1)，また(2) NCS-1の KO 心臓ではフェニレフリン刺 激による心肥大が抑制された (Fig. 4C). 以上の結果は, NCS-1 が IP3 受容体活性化などを介してホルモン刺激 
による心肥大を立進させることを強く示唆している。

このように, いくつかの $\mathrm{Ca}^{2+}$ 結合タンパク質は心肥 大に関与していることが報告されている。たとえば $\mathrm{S} 100 \mathrm{~B}$ と呼ばれる $\mathrm{Ca}^{2+}$ 結合タンパク質は, 心筋梗塞の 際に細胞外に分泌され心肥大を抑制する ${ }^{15)}$. 一方, CIB1 と呼ばれる $\mathrm{Ca}^{2+}$ 結合タンパク質は, カルシニューリン と相互作用することにより心肥大を六進させる ${ }^{16)}$. 興 味深いことに, CIB1 はNCS-1 と同様に未成熟期と心 肥大の際, 高発現している。

以上のように, NCS-1, IP3 受容体, CaMKII の 3 者は, いずれも未成熟期および心肥大の際に発現量が増加す ることから,これらの時期に共通した $\mathrm{Ca}^{2+}$ 制御のメカ ニズムが存在するのかもしれない.

\section{おわりに}

KO マウスを用いた研究により, NCS-1の心筋にお ける機能が初めて明らかとなった. NCS-1 は, 幼少期 の心筋の $\mathrm{Ca}^{2+}$ シグナルを増加させ, 収縮機能を充進さ せる1 ${ }^{1)}$. 幼少期の心臟は，T管や SR が成体と比べ，は るかに未発達であるにもかかわらず SRに依存した E-Cカップリングが行われていることから, 幼少期特 有の未知なる $\mathrm{Ca}^{2+}$ シグナル調節機構の存在が予測され ていた，本研究により，その1つとしてNCS-1，IP3 受 容体, CaMKII の 3 者の機能連関によって成立する巧妙 な機構が幼少期に存在することが示唆された。すなわ ち, 幼少期の心筋ではこの 3 者が高発現し, NCS-1 が $\mathrm{IP}_{3}$ 受容体を活性化することにより局所の心筋 $\mathrm{Ca}^{2+}$ シ グナルが増加する。これが CaMKII を活性化する $\mathrm{Ca}^{2+}$ 供給源となり,下流のシグナルの活性化 (CaMKII による PLB のリン酸化 $\rightarrow \mathrm{SR}$ Ca ポンプ活性の上昇 $\rightarrow \mathrm{SR} \mathrm{Ca}^{2+}$ 貯留量の上昇)により, グローバルな細胞内 $\mathrm{Ca}^{2+}$ トラン ジェントが増加し心筋収縮力を増加させるのではない かと考えられる (Fig. 4A)。この研究によって, 今まで あまり研究がなされていなかった幼少期の E-C カップ リングの機構に新たな 1 ページを加えることができた と思われる。なお, 胎児期, 生後直後に高発現し, この 時期の $\mathrm{Ca}^{2+}$ トランジェントへの関与が高いと報告され ている $\mathrm{T}-$ タイプ $\mathrm{Ca}^{2+}$ チャネルや $\mathrm{NCX}$ などの発現量は, 今回, WT と KO で大きく差はなかったものの, NCS-1 との物理的・機能的相互作用に関しては今後の課題で ある。

一方, NCS-1 は幼少期の心機能立進作用のみならず, 病的な心肥大が形成される時期にも発現量が上昇し, 病態にも寄与することを私たちは明らかにした ${ }^{1)}$ 。これ らの知見は, 小児科領域の心臓生理を理解するのみな
らず，病的心肥大を軽減する薬物開発にも役立つ可能 性がある。この研究を契機に, 広く心筋 $\mathrm{Ca}^{2+}$ シグナル 調節機構についてさらなる理解を深めていきたい.

\section{謝 辞}

$\mathrm{IP}_{3}$ 受容体 1 〜 3 のクローンの提供, ならびに $\mathrm{IP}_{3}$ 受 容体を用いた実験に関してご助言をいただいた，理化 学研究所脳科学総合研究センターの御子柴克彦先生, またNCS-1のKO マウスの共同入手に関わった Andreas Jeromin 博士に, 深く感謝いたします。

\section{【参考文献】}

1) Nakamura TY, Jeromin A, Mikoshiba K, et al: Neuronal calcium sensor-1 promotes immature heart function and hypertrophy by enhancing $\mathrm{Ca}^{2+}$ signals. Circ Res 2011; 109: 512-523

2) Nakamura TY, Wakabayashi S: Role of neuronal calcium sensor-1 in the cardiovascular system. Trends Cardiovasc Med 2012; 22: 12-17

3) Nakamura TY, Wakabayashi S: Diverse functions of neuronal calcium sensor-1 (NCS-1) in excitable cells. Trends in Cell \& Molecular Biology 2012; 7: 99-110

4) Wetzel GT, Klitzner TS: Developmental cardiac electrophysiology recent advances in cellular physiology. Cardiovasc Res 1996; 31: E52-E60

5) Haddock PS, Coetzee WA, Cho E, et al: Subcellular $\left[\mathrm{Ca}^{2+}\right] \mathrm{i}$ gradients during excitation-contraction coupling in newborn rabbit ventricular myocytes. Circ Res 1999; 85: 415-427

6) Nakamura TY, Pountney DJ, Ozaita A, et al: A role for frequenin, a $\mathrm{Ca}^{2+}$-binding protein, as a regulator of $\mathrm{Kv} 4 \mathrm{~K}^{+}-$ currents. Proc Natl Acad Sci USA 2001; 98: 12808-12813

7) Nakamura TY, Jeromin A, Smith G, et al: Novel role of neuronal $\mathrm{Ca}^{2+}$ sensor-1 as a survival factor up-regulated in injured neurons. J Cell Biol 2006; 172: 1081-1091

8) Nakamura TY, Sturm E, Pountney DJ, et al: Developmental expression of NCS-1 (frequenin), a regulator of Kv4 $\mathrm{K}^{+}$ channels, in mouse heart. Pediatr Res 2003; 53: 554-557

9) Kockskamper J, Zima AV, Roderick HL, et al: Emerging roles of inositol 1,4,5-trisphosphate signaling in cardiac myocytes. J Mol Cell Cardiol 2008; 45: 128-147

10) Uchida K, Aramaki M, Nakazawa M, et al: Gene knock-outs of inositol 1,4,5-trisphosphate receptors types 1 and 2 result in perturbation of cardiogenesis. PLoS One 2010; 5

11) Nakazawa M, Uchida K, Aramaki M, et al: Inositol 1,4,5-trisphosphate receptors are essential for the development of the second heart field. J Mol Cell Cardiol 2011; 51: 58-66

12) Schlecker C, Boehmerle W, Jeromin A, et al: Neuronal calcium sensor-1 enhancement of InsP3 receptor activity is 
inhibited by therapeutic levels of lithium. J Clin Invest 2006;

116: $1668-1674$

13) Zhang K, Heidrich FM, DeGray B, et al: Paclitaxel accelerates spontaneous calcium oscillations in cardiomyocytes by interacting with NCS-1 and the InsP3R. J Mol Cell Cardiol 2010； 49：829-835

14) Heineke J, Molkentin JD: Regulation of cardiac hypertrophy by intracellular signalling pathways. Nat Rev Mol Cell Biol
$2006 ; 7: 589-600$

15) Tsoporis JN, Marks A, Haddad A, et al: S100B expression modulates left ventricular remodeling after myocardial infarction in mice. Circulation 2005; 111: 598-606

16) Heineke J, Auger-Messier M, Correll RN, et al: CIB1 is a regulator of pathological cardiac hypertrophy. Nat Med $2010 ; 16: 872-879$ 